\title{
Silibinin Inhibits Adipogenesis and Induces Apoptosis in 3T3-L1 Adipocytes
}

\author{
Seul Gi Lee', Taeg Kyu Kwon², and Ju-Ock Nam ${ }^{1,3 *}$ \\ ${ }^{1}$ Department of Food Science and Biotechnology, Kyungpook National University, Daegu 41566, Republic of Korea \\ ${ }^{2}$ Department of Immunology, School of Medicine, Keimyung University, Daegu 41931, Republic of Korea \\ ${ }^{3}$ Institute of Agricultural Science \& Technology, Kyungpook National University, Daegu 41566, Republic of Korea
}

Received: October 24, 2016 / Revised: March 14, 2017 / Accepted: March 15, 2017

\begin{abstract}
C/EBP $\beta$ and C/EBP $\delta$ are required for the initiation of adipogenesis and induce the expression of key adipogenic regulators, such as PPAR $\gamma$ and $\mathrm{C} / \mathrm{EBP} \alpha$. In the present study, we have examined the effects of silibinin and its possible molecular mechanisms in regulating adipocyte differentiation and expression of $\mathrm{C} /$ EBP $\beta$ and C/EBP $\delta$ in the early stage of adipogenesis. Silibinin statistically significantly inhibits intracellular lipid accumulation and the mRNA expression of various genes involved at different stages during adipogenesis. Silibinin also suppresses expression of lipoprotein lipase (LPL), fatty acid binding protein 4 (AP2), and adiponectin in 3T3-L1 adipocytes. Thus, the anti-adipogenic effect of silibinin seems to originate from the ability to inhibit the expression of C/EBP $\beta$ and C/EBP $\delta$. Furthermore, silibinin decreases cell viability for differentiation period and induces apoptotic cell death through capspase-3 activation.
\end{abstract}

Keywords: 3T3-L1 adipocytes, anti-adipogenic, obesity, silibinin, Silybum marianum

\section{Introduction}

Obesity is a global health problem that is associated with an increased risk of numerous diseases, including diabetes, metabolic syndrome, and cardiovascular disease $[1,2]$. Excessive body fat, i.e. an increase in adipose tissue mass, results from adipogenesis and increased deposition of cytoplasmic triglycerides (TGs) [3]. Adipose tissue mass can be reduced by inhibiting adipogenesis or by inducing apoptosis of preadipocytes and mature adipocytes [4]. Adipogenesis is characterized by hyperplasia (increased number) and hypertrophy (increased size) of adipocytes. Adipogenesis is tightly controlled by several transcription factors, including peroxisome proliferatoractivated receptor gamma (PPAR $\gamma$ ) and CCAAT/ enhancer binding proteins $(\mathrm{C} / \mathrm{EBP} \beta, \mathrm{C} / \mathrm{EBP} \delta$, and $\mathrm{C} /$

\section{*Corresponding author}

Tel: +82-53-950-7760, Fax: +82-53-950-7762

E-mail: namjo@knu.ac.kr

๑ 2017, The Korean Society for Microbiology and Biotechnology
$\mathrm{EBP} \alpha$ ), that are necessary for the expression of many adipogenic genes, including fatty acid synthase (FAS) and adipocyte fatty acid-binding protein (aP2) [5]. C/ $\mathrm{EBP} \beta$ and $\mathrm{C} / \mathrm{EBP} \delta$ are expressed in the early phase of adipogenesis and induce proliferation of non-confluent adipocytes. This process, known as mitotic clonal expansion (MCE), is essential for adipocyte differentiation $[6,7]$. Understanding these processes is important in developing drugs to control obesity.

Flavonoids have recently attracted considerable interest as potential therapeutics against cancer, obesity, and cardiovascular disease [8, 9]. Among the various flavonoids, silibinin (also known as silybin), extracted from the milk thistle (Silybum marianum), has been reported to have anti-oxidative and anti-inflammatory actions [10, 11]. In addition, several studies have demonstrated direct effects of silibinin on adipocyte differentiation, but the mechanism of this action is not well understood [12, 13].

Therefore, in the present study, we have investigated 
the effects of silibinin on adipogenesis and the related molecular mechanisms.

\section{Materials and Methods}

\section{Chemical reagents}

Silibinin, Dulbecco's Modified Eagle's Medium (DMEM), antibiotics (100,000 unit/l penicillin, $100 \mathrm{mg} / \mathrm{l}$ streptomycin), fetal bovine serum (FBS), and bovine calf serum (BCS) were purchased from Gibco (USA). Insulin, 3isobutyl-1-methylxanthine (IBMX), dexamethasone (DEX), indomethacin, and Oil Red O (ORO) reagent were purchased from Sigma-Aldrich (USA) and 3-[4,5-dimethylthiazol-2-yl]-2,5-diphenyltetrazolium bromide (MTT) was purchased from Amresco (USA). A triglyceride quantification kit (\#K622-100) was supplied by Biovision Inc. (USA). Trizol reagent was obtained from Invitrogen (USA). Primary antibodies were obtained from the following sources: anti-pro-caspase-3, anti-cleaved-caspase3, anti-p38, anti-p-p38, and anti-C/EBP $\alpha$ antibodies from Cell Signaling Technology (USA), anti-PPAR $\gamma$ and antiadiponectin antibodies from Abcam plc (UK), anti- $\beta$ actin antibody from Santa Cruz Biotechnology (USA).

\section{Cell culture and differentiation}

The 3T3-L1 mouse cell line was purchased from the Korean Cell Line Bank (Korea) and maintained in DMEM with $10 \% \mathrm{BCS}$ at $37^{\circ} \mathrm{C}$ in a humidified $5 \% \mathrm{CO}_{2}$ incubator. The 3T3-L1 cells were seeded into six-well plates and differentiated into mature adipocytes. To induce differentiation, 2 days after reaching confluency (designated as day 0), the cells were stimulated with MDI solution (0.5 mM IBMX, $0.25 \mu \mathrm{M}$ DEX, $167 \mathrm{nM}$ insulin, and $100 \mu \mathrm{M}$ indomethacin) in DMEM and 10\% FBS for 2 days (from day 0 to day 2). The culture medium was then replaced with DMEM supplemented with 10\% FBS and insulin (from day 2 to day 9), which was changed every 2 days. To examine the effect of silibinin on adipogenesis, the cells were cultured with the differentiation medium in the presence or absence of silibinin (7.5 or $75 \mu \mathrm{M})$.

\section{Cell viability (MTT assay)}

The 3T3-L1 cells were seeded in ninety-six-well plates at a density of $3 \times 10^{3}$ cells/well and induced to undergo adipocyte differentiation or not induced. After incuba- tion, 3T3-L1 preadipocytes and differentiated adipocytes were treated with silibinin $(7.5$ or $75 \mu \mathrm{M})$ or were left untreated. At the end of the treatment, the culture medium was removed and replaced with MTT solution $(0.5 \mathrm{mg} / \mathrm{ml})$. The cells were then incubated for $3 \mathrm{~h}$ at $37^{\circ} \mathrm{C}$ followed by treatment with isopropyl alcohol (Duksan pure chemicals, Korea). The absorbance of each sample was measured at $495 \mathrm{~nm}$.

\section{Oil Red 0 staining}

For staining, 3T3-L1 cells were treated with silibinin (7.5 and $75 \mu \mathrm{M}$ ) for 8 days during adipogenesis or were left untreated. The cells were washed with phosphatebuffered saline (PBS) and fixed with $5 \%$ formalin for $1 \mathrm{~h}$ at room temperature. The cells were then washed with $60 \%$ isopropanol, stained with $0.4 \%$ ORO for $10 \mathrm{~min}$ at room temperature, washed 4 times with distilled water and photographed with a microscope at $200 \times$ magnification. Images of 3 random fields from 3 replicate wells were obtained and cells stained with Oil Red O solution was dissolved in isopropanol and then the absorbance was measured at $495 \mathrm{~nm}$.

\section{Triglyceride colorimetric assay}

TG content was determined using a TG Quantification Kit (Bio Vision) according to the manufacturer's instructions. At the end of the treatment, mature 3T3-L1 adipocytes were washed with PBS, homogenized in TG assay buffer containing $5 \%$ Nonidet P- 40 , heated to $80^{\circ} \mathrm{C}$ for $4 \mathrm{~min}$, centrifuged at $16,000 \times \mathrm{g}$ for $2 \mathrm{~min}$ to remove insoluble materials and diluted in $\mathrm{dH}_{2} \mathrm{O}$. The samples were mixed with a TG reaction mixture and incubated at room temperature for $1 \mathrm{~h}$. Colorimetric intensity was determined at $570 \mathrm{~nm}$.

\section{Reverse transcription-polymerase chain reaction (RT-PCR)}

Total RNA was extracted from 3T3-L1 adipocytes using RNAiso Plus reagent (TaKaRa Bio, Japan). RNA was used for complimentary DNA (cDNA) synthesis using the Prime-Script RT reagent Kit (TaKaRa Bio, Japan) according to the manufacturer's protocol. PCR amplification of the cDNA products was performed with GT PCR Master Mix (TaKaRa Bio, Japan). Amplification consisted of 35 cycles as follows: denaturing at $95^{\circ} \mathrm{C}$ for $30 \mathrm{~s}$, annealing at $60^{\circ} \mathrm{C}$ for $30 \mathrm{~s}$, and extension at $72^{\circ} \mathrm{C}$ for $45 \mathrm{~s}$, followed by a final $10 \mathrm{~min}$ extension at $72^{\circ} \mathrm{C}$. 
Table 1. The primer sequences for adipogenic genes.

\begin{tabular}{|c|c|c|c|}
\hline Gene name & Accession no. & Forward primer & Reverse primer \\
\hline $\mathrm{aP2}$ & NM_024406 & AACACCGAGATTTCCTTCAA & TCACGCCTTTCATAACACAT \\
\hline Adiponectin & NM_009605 & ACCTACGACCAGTATCAGGAAAAG & ACTAAGCTGAAAGTGTGTCGACTG \\
\hline C/EBP $\alpha$ & NM_001287523 & TTACAACAGGCCAGGTTTCC & GGCTGGCGACATACAGATCA \\
\hline C/EBP $\beta$ & NM_009883 & GACTACGCAACACACGTGTAACT & CAAAACCAAAAACATCAACAACCC \\
\hline C/EBP $\delta$ & NM_007679 & GATCTGCACGGCCTGTTGTA & CTCCACTGCCCACCTGTC \\
\hline LPL & NM_008509 & TCCTCTGACATTTGGCAGGTCTATC & TCACGCCTTTCATAACACAT \\
\hline PPAR $\gamma$ & AB644275 & TTTTCAAGGGTGCCAGTTTC & AATCCTTGGCCCTCTGAGAT \\
\hline$\beta$-actin & EF095208 & GACAACGGCTCCGGCATGTGCAAAG & TTCACGGTTGGCCTTAGGGTTCAG \\
\hline
\end{tabular}

PCR products were electrophoresed on a $1.2 \%$ agarose gel and the gel was stained with ethidium bromide. The sequences of the designed primers are shown in Table 1. $\beta$-actin was used as the control gene.

\section{Western blot analysis}

Cell lysates were prepared using radioimmunoprecipitation assay (RIPA) lysis buffer (Biosesang, Korea). Protein samples were separated on 10-15\% SDS-PAGE, transferred onto nitrocellulose membranes, blocked using 5\% non-fat skim milk in TBST (10 mM/ Tris $\mathrm{pH}$ 8.0, $150 \mathrm{mM} / \mathrm{l} \mathrm{NaCl}, 0.05 \%$ Tween 20) and incubated with primary antibodies overnight at $4{ }^{\circ} \mathrm{C}$. The membrane was incubated with HRP-conjugated secondary antibodies for $1 \mathrm{~h}$ at room temperature. The proteins were detected using enhanced chemiluminescence (ECL) reagent (GE Healthcare, UK).

\section{Statistical analysis}

Data were analyzed using SPSS version 21.0 (IBM Corporation, USA). Statistical comparisons between groups were performed using 1-way ANOVA. Values of $p$ $<0.05$ were considered statistically significant.

\section{Results}

\section{Effects of silibinin on differentiation and lipid accumula- tion of 3T3-L1 cells}

Lipid accumulation in adipocytes is one of the hallmarks of adipogenesis [14]. To investigate the effects of silibinin on the differentiation of 3T3-L1 preadipocytes into mature adipocytes, we treated the cells with silibinin at concentrations of 7.5 or $75 \mu \mathrm{M}$ for 8 days and performed ORO staining and a TG colorimetric assay. We found that silibinin inhibits the differentiation of 3T3-L1 cells in a concentration-dependent manner (Fig. 1A). During differentiation, cells normally change morphology to a more rounded shape and accumulate lipid droplets. Cells treated with silibinin at either concentration exhibited a small and spindle-like morphology. ORO staining revealed that the number of lipid droplets in the differentiated cells treated with silibinin was significantly less than in the untreated control. (Fig. 1B). Quantification of ORO staining demonstrated that the 7.5 and $75 \mu \mathrm{M}$ concentrations of silibinin significantly decreased the amount of lipid accumulation, by $61.2 \%$ and $42.8 \%$, respectively (Fig. 1C). In addition, silibinin at concentrations of 7.5 and $75 \mu \mathrm{M}$ markedly decreased intracellular TG levels, by $41.4 \%$ and $28.4 \%$, respectively (Fig. 1D). These results show that the lowest silibinin concentration strongly inhibited the differentiation of 3T3-L1 preadipocytes into adipocytes and prevented lipid accumulation.

\section{Effect of silibinin on the mRNA and protein expression of adipogenesis-related genes during 3T3-L1 differentiation}

Adipocyte differentiation is accompanied by alterations in the expression of various transcriptional factors and adipogenesis-specific genes [14]. To investigate the mechanisms underlying the action of silibinin to suppress differentiation of 3T3-L1 cells, we treated cells that were in the process of differentiation with silibinin for 8 days and performed RT-PCR. Treatment with silibinin at concentrations of either 7.5 or $75 \mu \mathrm{M}$ significantly reduced mRNA expression of transcription factors PPAR, C/EBP $\alpha$, and $\mathrm{C} / \mathrm{EBP} \delta$ and also decreased the expression of adipocyte-specific genes, fatty acid-binding protein 4 (aP2), lipoprotein lipase (LPL), and adiponectin. 
A

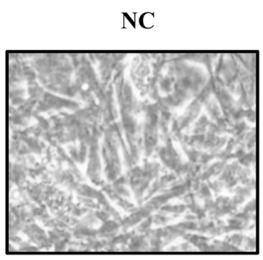

B

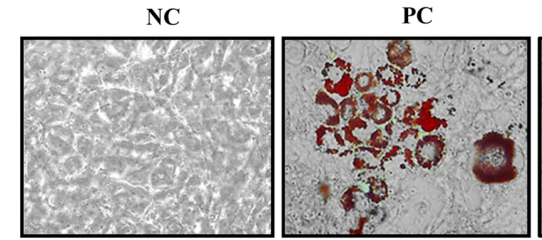

C

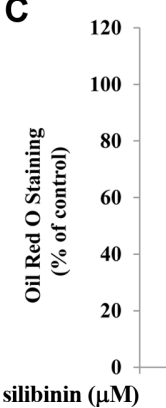

0

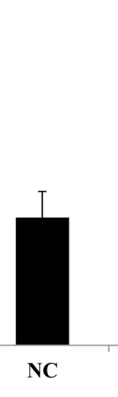

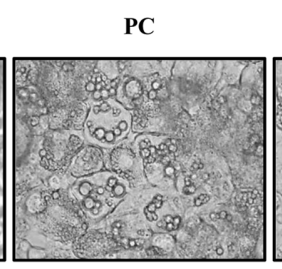

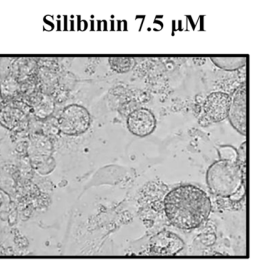

Silibinin $7.5 \mu \mathrm{M}$

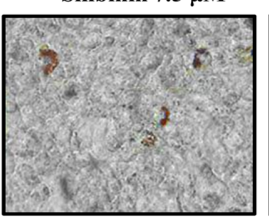

Silibinin $75 \mu \mathrm{M}$

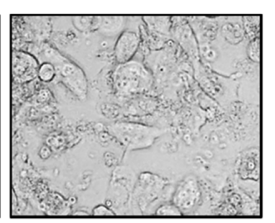

Silibinin $75 \mu \mathrm{M}$

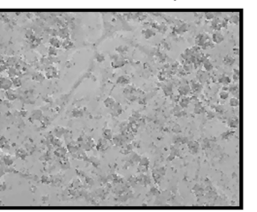

D

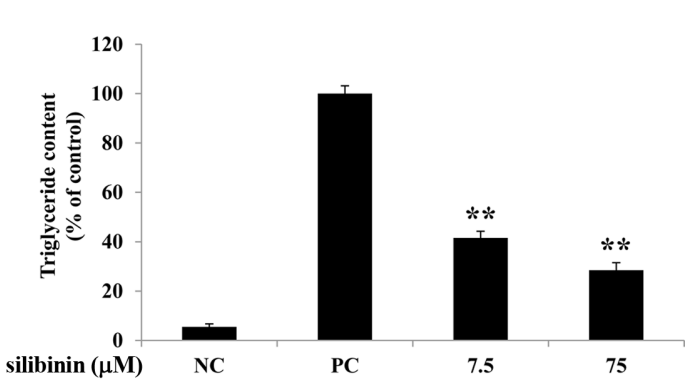

Fig. 1. Effects of silibinin on the differentiation and lipid accumulation of 3T3-L1 cells. 3T3-L1 preadipocytes were treated with silibinin ( 7.5 or $75 \mu \mathrm{M})$ for 8 days or were untreated. (A) After 8-days, the differentiated cells were photographed with a microscope at $400 \times$ magnification. (B) Intracellular lipid droplets were stained by ORO solution and observed at $200 \times$ magnification. (C) The ORO stained cells were measured as absorbance at $495 \mathrm{~nm}$. (D) Intracellular triglyceride concentrations measured as absorbance at $570 \mathrm{~nm}$. The preadipocytes were called negative control (NC) and fully differentiated adipocytes were called positive control (PC). PC were treated with the same amount of DMSO in place of silibinin. $P$ values of $<0.01(* *)$ or $<0.05(*)$. Bars represent mean \pm SD from three independent experiments.

The mRNA levels of C/EBP $\beta$ were not affected (Fig. 2). Thus, PPAR, C/EBP $\alpha$, and adiponectin were selected for subsequent western blotting studies. The results of the western blot analysis were similar to the RT-PCR. These results suggest that the inhibitory effect of silibinin on mRNA and protein expression was maintained until day 9, the termination stage of 3T3-L1 differentiation.

\section{Effects of silibinin on mRNA expression of the transcription factors that expressed in the early stage of adipogenesis}

$\mathrm{C} / \mathrm{EBP} \beta$ and $\mathrm{C} / \mathrm{EBP} \delta$ are critical determinants for the early stage of adipocyte differentiation and regulate the expression of cell type-specific genes [15, 16]. We therefore examined the effect of silibinin on mRNA expression levels of the early adipogenic transcription factors $\mathrm{C} /$ $\mathrm{EBP} \beta$ and $\mathrm{C} / \mathrm{EBP} \delta$ in the presence or absence of silibinin $(7.5$ or $75 \mu \mathrm{M})$ at different time points during differentiating days $1-3$. When cells were treated with silibinin,
$\mathrm{C} / \mathrm{EBP} \beta$ and $\mathrm{C} / \mathrm{EBP} \delta$ were decreased in a concentrationand time-dependent manner (Fig. 3). These results suggest that inhibition of adipocyte differentiation by silibinin may begin in the early stage of adipocyte differentiation.

\section{Silibinin showed cytotoxic effects through induction of apoptosis in differentiating adipocytes}

We performed an MTT assay to examine the effects of silibinin on the viability of 3T3-L1 preadipocytes or differentiated adipocytes. Silibinin $(7.5$ or $75 \mu \mathrm{M})$ had no significant effect on the viability and proliferation of 3T3-L1 preadipocytes (Fig. 4A). Additionally, the cytotoxicity of silibinin on differentiated adipocytes was assessed with 3T3-L1 cells induced to differentiate into mature adipocytes. Treatment with silibinin at concentrations of $75 \mu \mathrm{M}$ at all stages (0-8 days) or at late stages (4-8 days) of differentiation significantly decreased cell 


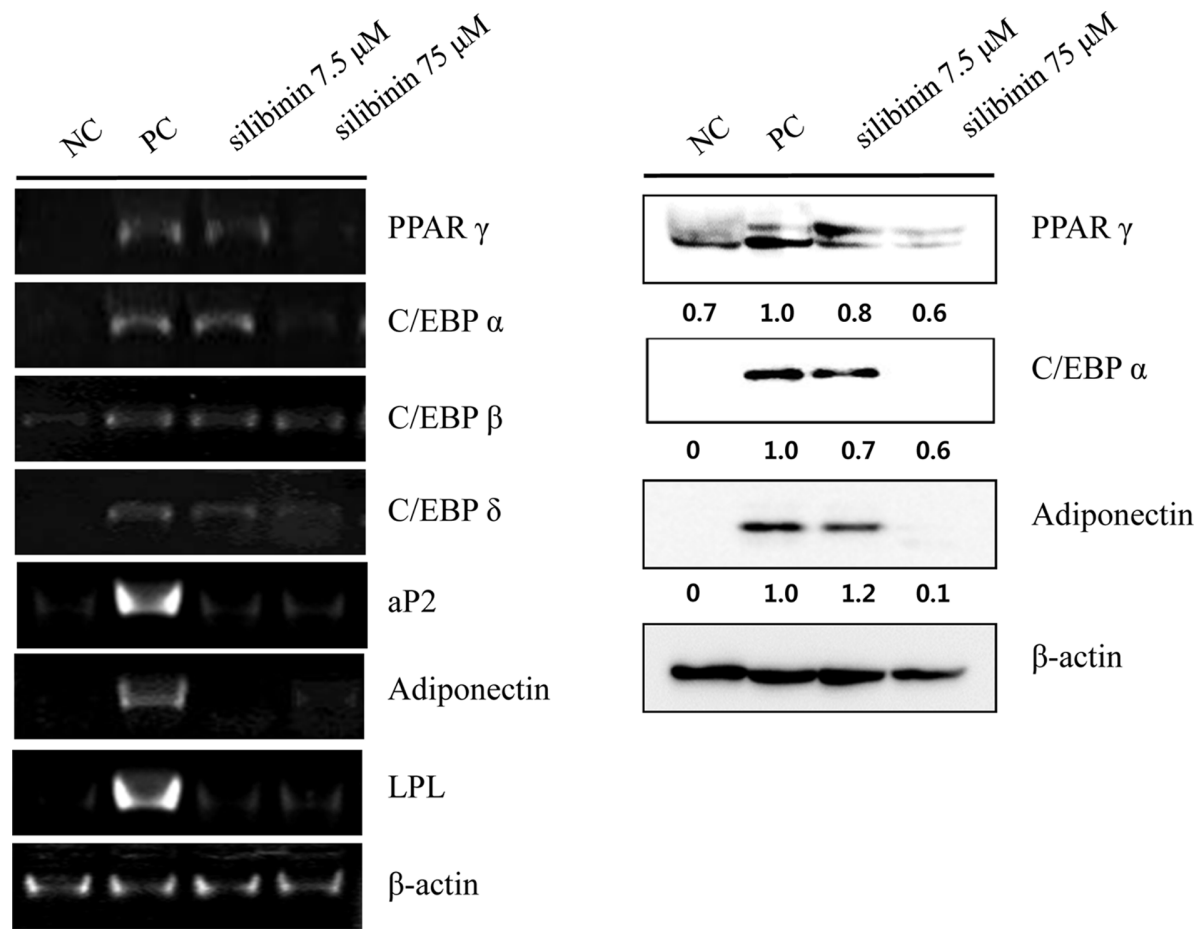

Fig. 2. Effects of silibinin on mRNA and protein expression of adipogenesis-related genes in 3T3-L1 adipocytes. 3T3-L1 preadipocytes cells were with silibinin $(7.5$ or $75 \mu \mathrm{M})$ for 8 days during differentiation or were untreated. Total RNA and protein was isolated from 3T3-L1 adipocytes at days 8 and confirmed the expression of adipogenic-related genes by RT-PCR and western blot analysis. Representative images for RT-PCR and western blot are shown on the left and right, respectively. $P$ values of $<0.01{ }^{* *}$ ) or $<0.05\left(^{*}\right)$. Bars represent mean \pm SD from three independent experiments.
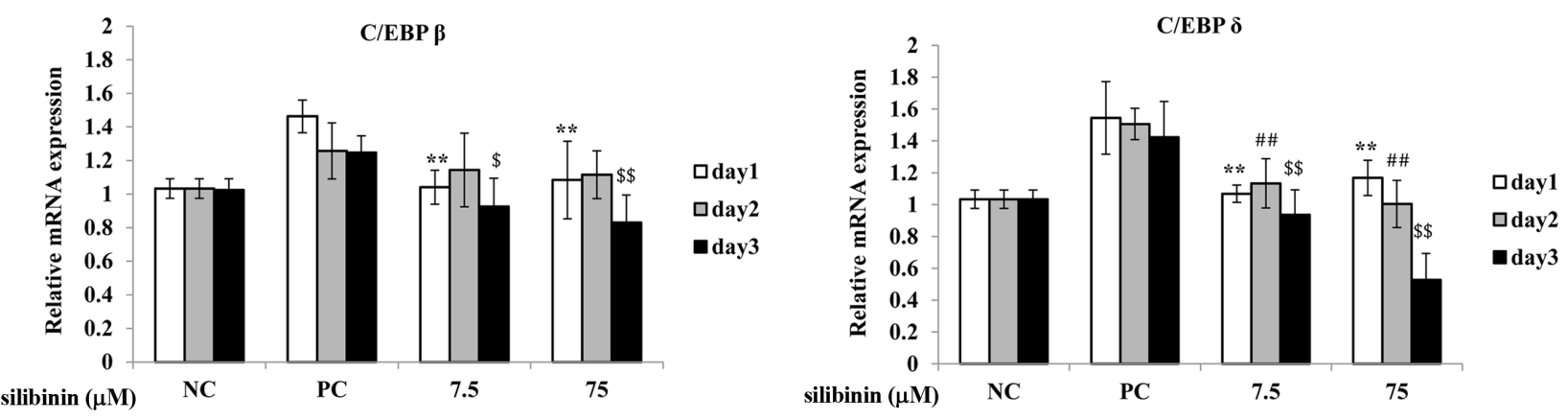

Fig. 3. Effect of silibinin on the mRNA expression of C/EBP $\beta$ and C/EBP $\delta$ at the early stages of adipogenesis. 3T3-L1 preadipocytes cells were treated with silibinin $(7.5$ and $75 \mu \mathrm{M})$ for 3 days or were left untreated. Total RNA was isolated from3T3-L1 adipocytes at days 1,2 , and 3 during differentiation. The mRNA expression of C/EBP $\beta$ and C/EBP $\delta$ were normalized to $\beta$-actin and shown as relative expression compared to the undifferentiated control group (NC) at all times. $p<0.05\left({ }^{*}\right), p<0.01\left({ }^{* *}\right)$ at day $1, p<0.05(\#), p<0.01$ $(\# \#)$ at day 2 and $p<0.05(\$), p<0.01$ (\$) at day 3 compared with untreated adipocytes at each gene expression. Bars represent mean \pm SD from three independent experiments.

viability (Fig. 4B). Treatment with silibinin at all stages had a greater cytotoxic effect than just treatment at late stages.

We hypothesized that cytotoxic effects of silibinin was predominantly due to apoptosis in differentiating adipocytes. To test this hypothesis, we examined the protein expression of apoptotic makers after the treatment of silibinin with MDI solution for $24 \mathrm{~h}$. Caspase-3 is an 


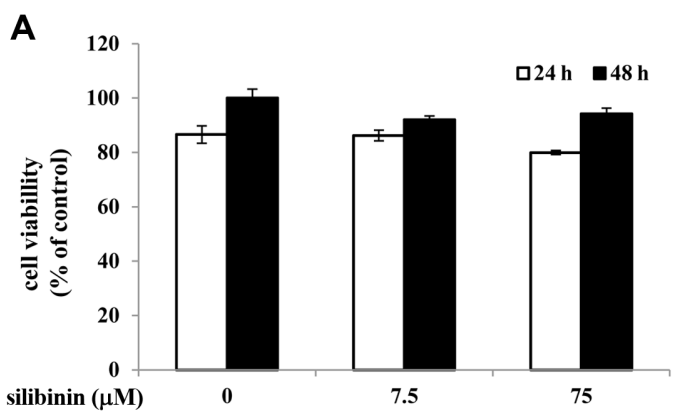

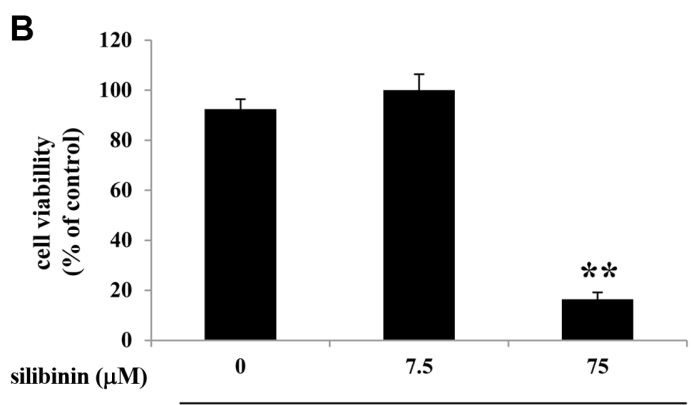

Treatment days 0-8

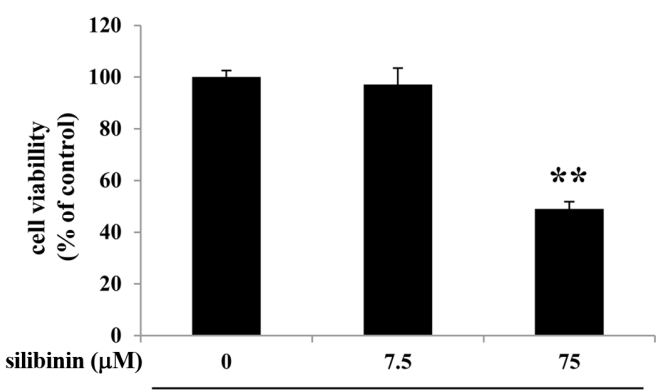

Treatment days 4-8

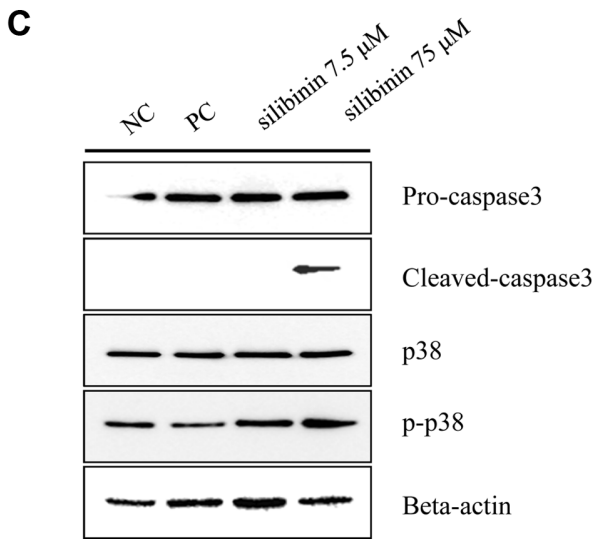

Fig. 4. Effects of silibinin on cell viability of 3T3-L1 preadipocytes and differentiated adipocytes. 3T3-L1 preadipocytes were treated with concentrations ( 7.5 or $75 \mu \mathrm{M}$ ) of silibinin for 24 and $48 \mathrm{~h}$ or were left untreated. (A) Cell viability was determined by MTT assay and measured as absorbance at $495 \mathrm{~nm}$. (B) 3T3-L1 preadipocytes were differentiated into adipocytes and treated with silibinin $(7.5$ or $75 \mu \mathrm{M})$ for the entire differentiation period (from day 0 to day 8) or after induction of differentiation (from day 4 to day 8). (C) 3T3-L1 cells were induced to differentiate into adipocytes with treatment of silibinin (7.5 or $75 \mu \mathrm{M})$ for $24 \mathrm{~h}$. Protein expression of pro-caspase-3, cleaved-caspase-3, p38, p-p38, and beta-actin were analyzed by western blot. An equal amount of loading was confirmed using $\beta$-actin. $P$ values of $<0.01\left(^{* *}\right)$ or $<0.05\left(^{*}\right)$. Bars represent mean \pm SD from three independent experiments.

effector of apoptosis and the activation of caspase-3 generally leads to cleavage of cytoplasmic [17]. P38 mitogenactivated protein kinase (p38) is activated and related with cleavage of caspase-3 during apoptosis by a number of stimuli [18]. We observed that cleaved-caspase-3 and p-p38 expression were significantly increased in silibinin treated cell (Fig. 4C). Total p38 and pro-caspase-3 expression were not changed under the same conditions. These results strongly imply that silibinin induces apoptosis of 3T3-L1 adipocytes during adipogenesis. 


\section{Discussion}

Adipogenesis and excessive fat accumulation in white adipose tissues are caused by excess energy intake and lack of activity and are the key features of obesity [19]. Anti-obesity drug development has focused on synthetic chemicals such as orlistat or sibutramine. However, because of the severe side effects of such chemicals, recent studies on anti-obesity agents have focused on natural compounds [14]. Silibinin, a natural flavonoid, has been suggested to exert anti-oxidative and anti-cancer effects and recent studies reported its anti-obesity actions on 3T3-L1 adipocytes [20, 21].

In this study, we have shown that silibinin suppressed the differentiation of 3T3-L1 preadipocytes into adipocytes. These observations are similar to those reported by Park et al. [12]. We have further elucidated the effect of silibinin at different time periods during adipocyte differentiation. We found that treatment of 3T3-L1 adipocytes with silibinin significantly decreased lipid accumulation and triglyceride levels in a concentration-dependent manner as measured by ORO staining and TG assay. To initiate the differentiation program, growth-arrested post-confluent 3T3-L1 preadipocytes were treated with hormonal agents [7, 22]. This treatment causes the preadipocytes to re-enter the cell cycle and undergo two rounds of division, a process referred to as MCE [23]. $\mathrm{MCE}$ is coordinated by dramatic induction of $\mathrm{C} / \mathrm{EBP} \beta$ and $\mathrm{C} / \mathrm{EBP} \delta$. These transcription factors promote the expression of PPAR $\gamma$ and $\mathrm{C} / \mathrm{EBP} \alpha$, the major transcription factors involved in adipocyte differentiation [1].

Differentiation of preadipocytes into mature adipocytes is mediated by consecutive activation of a complex transcriptional cascade and involves several stages. Therefore, we examined $\mathrm{C} / \mathrm{EBP} \beta$ and $\mathrm{C} / \mathrm{EBP} \delta$ mRNA expression after exposure to concentrations of silibinin at the early stage of differentiation (day 1-3) and found that silibinin down-regulated $\mathrm{C} / \mathrm{EBP} \beta$ and $\mathrm{C} / \mathrm{EBP} \delta$ expression at all times in a concentration- and timedependent manner.

Furthermore, silibinin significantly reduced the expression of $\mathrm{PPAR} \gamma, \mathrm{C} / \mathrm{EBP} \alpha$ and adipogenic-related genes, such as aP2, LPL and adiponectin, which are commonly used as adipocyte markers at terminal stage of differentiation (day 9). These results suggest that the inhibited expression of PPAR $\gamma$ and $\mathrm{C} / \mathrm{EBP} \alpha$ by silibinin is likely to be a consequence of decreased $\mathrm{C} / \mathrm{EBP} \beta$ and $\mathrm{C} /$ EBP $\delta$ at the early stage of differentiation.

Adipocyte apoptosis contributes to reduced adipose tissue mass, which indicate that cell- specific apoptotic events was able to prevent or treat obesity [24]. We confirmed that silibinin showed cytotoxic effect through apoptosis in differentiating adipocytes but does not affect preadipocyte survival. Our study clearly demonstrates the anti-adipogenesis effect of silibinin in differentiation of 3T3-L1 cells.

In summary, our results demonstrate that silibinin suppresses differentiation of 3T3-L1 cells by modulating the expression of central transcription factors and various adipogenesis-related genes at the early stage of differentiation and induces apoptosis in differentiating 3T3-L1 cells. Further research to elucidate the therapeutic role of silibinin in vivo in an obesity animal model is warranted.

\section{References}

1. Park JY, Kim Y, Im JA, You S, Lee H. 2014. Inhibition of adipogenesis by oligonol through Akt-mTOR inhibition in 3T3-L1 adipocytes. 2014: 11.

2. Yang JY, Della-Fera MA, Rayalam S, Ambati S, Hartzell DL, Park HJ, et al. 2008. Enhanced inhibition of adipogenesis and induction of apoptosis in 3T3-L1 adipocytes with combinations of resveratrol and quercetin. Life Sci. 82: 1032-1039.

3. Kim M, Park JE, Song SB, Cha YS. 2015. Effects of black adzuki bean (Vigna angularis) extract on proliferation and. Nutrients 7: 277-292.

4. Rayalam S, Yang JY, Ambati S, Della-Fera MA, Baile CA. 2008. Resveratrol induces apoptosis and inhibits adipogenesis in 3T3-L1 adipocytes. Phytotherapy Research:PTR. 22: 1367-1371.

5. Min B, Lee H, Song JH, Han MJ, Chung J. 2014. Arctiin inhibits adipogenesis in 3T3-L1 cells and decreases adiposity and body weight in mice fed a high-fat diet. Nutr. Res. Pract. 8: 655-661.

6. Lechner S, Mitterberger MC, Mattesich M, Zwerschke W. 2013. Role of C/EBPbeta-LAP and C/EBPbeta-LIP in early adipogenic differentiation of human white adipose-derived progenitors and at later stages in immature adipocytes. Differentiation 85: 20-31.

7. Hishida T, Nishizuka M, Osada S, Imagawa M. 2009. The role of C/ EBPdelta in the early stages of adipogenesis. Biochimie. 91: 654657.

8. Moon J, Do HJ, Kim OY, Shin MJ. 2013. Antiobesity effects of quercetin-rich onion peel extract on the differentiation of 3T3-L1 preadipocytes and the adipogenesis in high fat-fed rats. Food Chem. Toxicol. 58: 347-354.

9. Meltzer HM, Malterud KE. 1997. Can dietary flavonoids influence the development of coronary heart disease? Scand. J. Nutr. Nar- 
ingsforsk. 41: 50-57.

10. Wang HJ, Jiang YY, Lu P, Wang Q, Ikejima T. 2010. An updated review at molecular pharmacological level for the mechanism of anti-tumor, antioxidant and immunoregulatory action of silibinin. Yao xue xue bao = Acta pharmaceutica Sinica. 45: 413-421.

11. Cristofalo R, Bannwart-Castro CF, Magalhaes CG, Borges VT, Peracoli JC, Witkin SS, et al. 2013. Silibinin attenuates oxidative metabolism and cytokine production by monocytes from preeclamptic women. Free Radical Res. 47: 268-275.

12. Ka SO, Kim KA, Kwon KB, Park JW, Park BH. 2009. Silibinin attenuates adipogenesis in 3T3-L1 preadipocytes through a potential upregulation of the insig pathway. Int. J. Molecul. Med. 23: 633637.

13. Suh HJ, Cho SY, Kim EY, Choi HS. 2015. Blockade of lipid accumulation by silibinin in adipocytes and zebrafish. Chemico-biological Interactions 227: 53-62.

14. Yoo SR, Seo CS, Shin HK, Jeong SJ. 2015. Traditional herbal formula Oyaksungi-San inhibits adipogenesis in 3T3-L1 adipocytes. 2015: 949461.

15. Lefterova MI, Lazar MA. 2009. New developments in adipogenesis. Trends in Endocrinology and Metabolism: TEM. 20: 107-114.

16. Kim M, Park JE, Song SB, Cha YS. 2015. Effects of black adzuki bean (Vigna angularis) extract on proliferation and differentiation of 3T3-L1 preadipocytes into mature adipocytes. Nutrients 7: 277-292.

17. Porter AG, Janicke RU. 1999. Emerging roles of caspase-3 in apoptosis. Cell Death and Differentiation 6: 99-104.
18. Zhuang S, Demirs JT, Kochevar IE. 2000. p38 mitogen-activated protein kinase mediates bid cleavage, mitochondrial dysfunction, and caspase-3 activation during apoptosis induced by singlet oxygen but not by hydrogen peroxide. J. Biol. Chem. 275: 25939-25948.

19. Vigneri P, Frasca F, Sciacca L, Pandini G, Vigneri R. 2009. Diabetes and cancer. Endocrine-related Cancer. 16: 1103-1123.

20. Dhanalakshmi S, Singh RP, Agarwal C, Agarwal R. 2002. Silibinin inhibits constitutive and TNFalpha-induced activation of NF-kap$\mathrm{paB}$ and sensitizes human prostate carcinoma DU145 cells to TNFalpha-induced apoptosis. Oncogene 21: 1759-1767.

21. Katiyar SK. 2005. Silymarin and skin cancer prevention: antiinflammatory, antioxidant and immunomodulatory effects (Review). Int. J. Oncol. 26: 169-176.

22. Qiu Z, Wei Y, Chen N, Jiang M, Wu J, Liao K. 2001. DNA synthesis and mitotic clonal expansion is not a required step for 3T3-L1 preadipocyte differentiation into adipocytes. J. Biol. Chem. 276: 11988-11995.

23. Lane MD, Tang QQ, Jiang MS. 1999. Role of the CCAAT enhancer binding proteins (C/EBPs) in adipocyte differentiation. Biochemical and Biophysical Research Communications 266: 677-683.

24. Sun X, Zemel MB. 2004. Role of uncoupling protein 2 (UCP2) expression and 1alpha, 25-dihydroxyvitamin D3 in modulating adipocyte apoptosis. FASEB Journal : Official Publication of the Federation of American Societies for Experimental Biology 18 : 1430-1432.

\title{
국문초록
}

\author{
Silibnin의 지방세포분화 억제 및 세포사멸 유도 효과 \\ 이슬기 ${ }^{1}$, 권택규 ${ }^{2}$, 남주옥 ${ }^{1,3 *}$ \\ 1 경북대학교 농업생명과학대학 식품공학부 \\ 2 계명대학교 의과대학 면역학교실 \\ 3 경북대학교 농업과학기술연구소
}

CCAAT/enhancer-binding protein beta, delta $(\mathrm{C} / \mathrm{EBP} \beta, \delta)$ 는 지방세포분화 과정의 초기에 필수적으로 요구되며 지방생성 주요 조절인자인 proliferator-activated receptor gamma (PPAR $\gamma)$ and CCAAT/enhancer-binding protein-alpha (C/EBP $\alpha)$ 의 발현을 유도한다. 본 연구에서는 silibinin의 지방세포 분화 억제 효과 및 이러한 효과가 지방세포 분화초기에 $\mathrm{C} / \mathrm{EBP} \beta$ 및 $\mathrm{C} / \mathrm{EBP} \delta$ 의 발 현 조절을 통해 일어난 다는 것을 확인하였다. Silibinin은 지방세포 내 지질축적을 억제하고 세포분화 과정 동안 관여하는 다양 한 유전자의 mRNA 발현을 억제하였다. 또한 lipoprotein lipase (LPL), fatty acid binding protein 4 (AP2) 및 adiponectin과 같 은 지방세포 분화 관련 유전자의 발현을 억제시켰다. 따라서, Silibinin의 지방세포 분화 억제효과는 $\mathrm{C} / \mathrm{EBP} \beta$ 및 $\mathrm{C} / \mathrm{EBP} \delta$ 의 발현 억제에 의한 것으로 보인다. 더불어, Silibinin은 capspase- 3 활성을 통해 분화하는 세포에 특이적으로 세포사멸을 유도하는 것을 확인하였다. 